\title{
Growth performance and nutritional quality enrichment of Phronima pacifica by Chlorella vulgaris and Chaetoceros calcitrans as natural feed
}

\author{
VIVI ENDAR HERAWATI ${ }^{1, \bullet}$, ZUMALALLAIL NAILULMUNA ${ }^{2}$, NURMANITA RISMANINGSIH ${ }^{3}$, \\ JOHANNES HUTABARAT ${ }^{1}$, PINANDOYO ${ }^{1}$, TITA ELFITASARI ${ }^{1}$, PUTUT HAR RIYADI $^{4}$, \\ OCKY KARNA RADJASA ${ }^{5}$ \\ ${ }^{1}$ Department of Aquaculture, Faculty of Fisheries and Marine Sciences, Universitas Diponegoro. J1. Prof. H. Soedarto, S.H., Semarang 50275, Central \\ Java, Indonesia. Tel./fax.: +62-24-7474698, `email: viviendar23@gmail.com \\ ${ }^{2}$ Department of Coastal Resource Management, Faculty of Fisheries and Marine Science, Universitas Diponegoro. J1. Prof. H. Soedarto, S.H., Semarang \\ 50275, Central Java, Indonesia \\ ${ }^{3}$ Department of Materials Chemistry, Graduate School of Engineering, Nagoya University. Furo-cho, Chikusa-ku, Nagoya 464-8603, Japan \\ ${ }^{4}$ Department of Fisheries Product Technology, Faculty of Fisheries and Marine Sciences, Universitas Diponegoro. Jl. Prof. H. Soedarto, S.H., Semarang \\ 50275, Central Java, Indonesia \\ ${ }^{5}$ Department of Marine Science, Faculty of Fisheries and Marine Sciences, Universitas Diponegoro. J1. Prof. H. Soedarto, S.H., Semarang 50275, Central \\ Java, Indonesia
}

Manuscript received: 29 June 2020. Revision accepted: 24 August 2020.

\begin{abstract}
Herawati VE, Nailulmuna Z, Rismaningsih N, Hutabarat J, Pinandoyo, Elfitasari T, Riyadi PH, Radjasa OK. 2020. Growth performance and nutritional quality enrichment of Phronima pacifica by Chlorella vulgaris and Chaetoceros calcitrans as natural feed. Biodiversitas 21: 4253-4259. Phronima pacifica as a natural feed has the potential to replace Artemia sp. because of its high nutritional content. The purpose of this study was to determine the effects of different types of feed for $P$. pacifica during its culture on its population density, growth rate, and nutritional content because of its potential use as a natural feed for fish. The test animals in this study consisted of $P$. pacifica at a stocking density of 3 ind./L, which were cultured for $18 \mathrm{~d}$. Then, Chlorella vulgaris and Chaetoceros calcitrans were introduced as enrichment feed for P. pacifica. This study used a completely randomized design with three treatments and three replications. The treatments were as follows: A (100\% C. vulgaris), B (100\% C. calcitrans), and C (50\% C. vulgaris and $50 \%$ C. calcitrans). The results showed that treatment increased the population density of $P$. pacifica by up to $54.67 \pm 0.0038$ ind./L by the $12^{\text {th }}$ day. Based on the results of proximate analysis for amino acid and fatty acid profiles, the highest values for proteins and fats were in $P$. pacifica enriched with $C$. vulgaris (A) and consisted of $45.45 \%$ protein, $7.57 \%$ fat, $5.95 \%$ eicosapentaenoic acid, and $39.23 \%$ lysine. Based on an ANOVA, feeding of $P$. pacifica with $C$. vulgaris and C. calcitrans had a significant effect on population density, relative growth rate, biomass production, and nutrient value of proteins and fats of $P$. pacifica $(\mathrm{P}<0.05)$. The best results, including population density, growth rate, weight of biomass, and nutrient content of $P$. pacifica, occurred after feeding with $C$. vulgaris.
\end{abstract}

Keywords: Amino acid, Chaetoceros calcitrans, Chlorella vulgaris, fatty acid, Phronima pacifica

\section{INTRODUCTION}

Phronima pacifica is a type of Amphipoda microcrustacean that lives at a depth from 0 to $25 \mathrm{~m}$ below sea level (Elder and Siebel 2015). Amphipoda has six suborders: Pseudingolfiellidea, Hyperiidea, Colomastigidea, Hyperiopsidea, Senticaudata, and Amphilochidea (Lowry and Myers 2017). P. pacifica belongs to the Hyperiidea suborder (Bishop and Geiger 2006). P. pacifica could be used as an alternative natural feed or a replacement for Artemia sp. P. pacifica has a high nutrient content, a size suitable for the mouth gap of fish and shrimp, and is easily mass cultured. $P$. pacifica is a nonselective filter feeder; thus, the addition of nutrients can be completed through aquaculture media (Aoki et al. 2013). The nutrient content of $P$. pacifica depends on the culture media used because it acts as its feed source (Fattah et al. 2014; Herawati et al. 2015).

Amphipoda can serve as a source of natural feed in aquaculture (Baeza-Rojano et al. 2013). P. pacifica has the potential to become a natural feed and serve as a substitution for Artemia sp. (Fattah et al. 2014), which is generally given to post-larvae shrimp. The selection of natural feed has various criteria such as the mouth gap of fish larvae and a nutritional content suitable for the needs of the cultured fish or shrimp (Herawati et al. 2014). The nutritional content of $P$. pacifica is particularly high in eicosapentaenoic acid (EPA) and docosahexaenoic acid (DHA); therefore, efforts are needed to support the development of $P$. pacifica, which can be a natural feed substitution, thereby reducing the use of the relatively expensive Artemia sp. Previous research regarding the replacement of Artemia sp. has focused on Phronima sp. as a natural feed substitute for tiger shrimp aquaculture (Penaeus monodon) and Litopenaeus vannamei post-larvae. Research conducted by Fattah et al. (2014) reported a survival rate of more than $80 \%$ and Herawati et al. (2020) using Phronima for vanname shrimp reported a survival rate of $95 \%$. 
Amphipoda belongs to zooplankton, which is a natural food for wild fish (Dalpadado and Bogstad 2004). The abundance of $P$. pacifica has been influenced by the feed in the culture media with the type of feed used being Chlorella vulgaris and Chaetoceros calcitrans. The nutrient content of Chlorella sp. was $45 \%$ protein, $20 \%$ fat, $20 \%$ carbohydrates, and $40 \%$ EPA (Fattah et al. 2014). Valverde et al. (2013) reported on microalgae that have high nutritional content, one of which was Chaetoceros sp. It had nutrient content consisting of proteins, carbohydrates, and fat with a percent dry weight of the Chaetoceros sp. microalgae diet consisting of $36 \%$ protein, $10 \%$ fat, $15 \%$ carbohydrate, and $15 \%$ EPA (Sihombing et al. 2013, Méndez-Martínez et al. 2018).

The type of feed affects the growth process and the nutritional quality of Phronima sp. The type of feed is also a factor that can support the development of $P$. pacifica as a natural feed substitute for Artemia sp. To date, there have been no studies that report on the effects of providing different types of natural feed on the nutritional content of $P$. pacifica. Previous research conducted by our team using various animal manures under a fermentation process was conducted using Daphnia magna and Tubifex mass culture. Based on the results, the use of chicken manure was the best treatment, providing higher nutritional quality and growth performance than did that of other treatments. The purpose of this study was to determine the growth performance, biomass production, and the quality of nutrients through proximate amino acids and fatty acids of P. pacifica.

\section{MATERIALS AND METHODS}

\section{Phronima pacifica culture}

Phronima pacifica, which were used as test animals, were kept at a stocking density of 3 ind./L. The culture media used was seawater with fine sand was added as a substrate. The seawater was first formulated, and then water for the culture media was prepared. After $1 \mathrm{~d}, P$. pacifica was stocked and cultured for $18 \mathrm{~d}$, and fertilizer was added every $3 \mathrm{~d}$. Growth observations and water quality measurements were recorded daily. The dietary enrichment used in this study consisted of the addition of C. vulgaris and/or C. calcitrans. P. pacifica feeding treatments were: A $(100 \%$ C. vulgaris $)$, B $(100 \% \quad C$. calcitrans.), C (50\% C. vulgaris and $50 \%$ C. calcitrans). Feeding was conducted at $10^{5}$ cells/individual density and occurred twice daily.

\section{Chlorella vulgaris culture}

The culture formula for Chlorella sp. was from a mass scale natural feed laboratory at BBBPAP Jepara. The formulation for the culture of Chaetoceros sp. at a bulk scale consisted of urea fertilizer 80 ppm, SP-36 40 ppm, ZA 60 ppm; NPK 1 ppm, and EDTA 5 ppm. Furthermore, the formulation was placed in $1000 \mathrm{~L}$ of sterile seawater and aerated continuously. To this media, $1 \mathrm{~L}$ of pure Chaetoceros sp. seeds was inserted. After $3 \mathrm{~d}$, the media was ready to be used as feed for Phronima sp. The harvesting process was conducted by filtering with a $10 \mu \mathrm{m}$ plankton net. The harvested contents were then used as $P$. pacifica feed.

\section{Chaetoceros calcitrans culture}

The formulation for the culture of Chaetoceros sp. at a bulk scale consisted of sodium dihydrogen phosphate $\left(\mathrm{NaOH}_{2} \mathrm{PO}_{4}\right) 150$ ppm, $\mathrm{KNO}_{3} 400$ ppm, $\mathrm{Na}_{2} \mathrm{SiO}_{3} 80$ ppm, EDTA $50 \mathrm{ppm}, \mathrm{FeCl}_{3} 10 \mathrm{ppm}$, and Vitamin $\mathrm{B}_{12} 0.01 \mathrm{ppm}$. Furthermore, the formulation was placed in $1000 \mathrm{~L}$ of sterile seawater and aerated continuously. To this media, 1 L of pure Chaetoceros sp. seeds was inserted. After 3 days, the media was ready to be used as feed for Phronima sp. The harvesting process was conducted by filtering with a $10 \mu \mathrm{m}$ plankton net. The harvested contents were then used as $P$. pacifica feed.

\section{Specific growth rate (r)}

The specific growth rate (ind/day) was calculated using the Krebs formula (1972), as follows:

$$
r=\frac{\ln N_{t}-\ln N_{0}}{t}
$$

Where: $\mathrm{r}$ : growth rate (ind/day); t: days needed to achieve maximum growth (days); $\mathrm{N}_{\mathrm{t}}$ density of Phronima sp. on day $\mathrm{t} ; \mathrm{N}_{0}$ : initial density of $P$. pacifica.

\section{Population density}

The population density of $P$. pacifica was calculated daily during the $18 \mathrm{~d}$ of aquaculture. Population density calculations were performed by taking $1 \mathrm{~L}$ of culture media from six sampling points and calculating the number of $P$. pacifica. At the time of sampling, the culture media was stirred in advance such that $P$. pacifica were evenly spread. The calculations were performed with three repetitions (Aoki et al. 2013).

\section{Biomass}

Measurement of biomass production to determine the number of plankton produced was conducted with a practical and simple method (Krebs 1972). Calculation of $P$. pacifica. biomass production was calculated using the following formula:

$$
\mathrm{W}=\mathrm{W}_{\mathrm{t}}-\mathrm{W}_{0}
$$

Where: W: biomass $(\mathrm{g}) ; \mathrm{W}_{0}$ : initial weight $(\mathrm{g}) ; \mathrm{W}_{\mathrm{t}}$ final weight $(\mathrm{g})$.

\section{Nutrient content}

Nutrient content was obtained from proximate analysis tests, which included proteins, carbohydrates, fats, crude fiber, and water content.

\section{Proximate analysis}

The proximate chemical composition of the samples was determined using a standard procedure (AOAC 2005; Herawati et al. 2018). The carbohydrate content was estimated based on the difference. 


\section{Essential amino acid profiles}

The amino acid composition of the sample was determined using high-performance liquid chromatography (HPLC) (Shimadzu LC-6A) (AOAC 2005; Herawati et al. 2018). The essential amino acid profile of $P$. pacifica was determined by examining its essential amino acid content. The essential amino acid analysis was conducted using an HPLC type 1100 with a Eurospher 100-5 C18, $250 \times 4.6$ $\mathrm{mm}$ column with a $\mathrm{P} / \mathrm{N} 1115 \mathrm{Y} 535$ pre-column. The effluents were A) $0.01 \mathrm{M}$ acetate buffer at $\mathrm{pH} 5.9$ and $\mathrm{B}$ ) $0.01 \mathrm{M} \mathrm{MeOH}$ acetate buffer at $\mathrm{pH}$ 5.9. Conditions were $\mathrm{THF}>80,15: 5 \Lambda$ fluorescence, Ext $340 \mathrm{~nm}$, and Em 450 $\mathrm{nm}$. Approximately $2.5 \mathrm{~g}$ of the sample was placed into a sealed glass. Then, $15 \mathrm{~mL}$ of $\mathrm{HCl} 6 \mathrm{~N}$ was added. The mixture was then vortexed for homogeneity and underwent hydrolysis using an autoclave at $110^{\circ} \mathrm{C}$ for $12 \mathrm{~h}$, before being cooled to room temperature and neutralized with $\mathrm{NaOH} 6 \mathrm{~N}$. After the addition of $2.5 \mathrm{~mL}$ of $40 \% \mathrm{~Pb}$ acetate and $1 \mathrm{~mL}$ of $15 \%$ oxalate acid, approximately $3 \mathrm{~mL}$ of the mixture was filtered with $0.45 \mu \mathrm{m}$ millex. For the injection for HPLC, $25 \mu \mathrm{L}$ of the filtered mixture plus $475 \mu \mathrm{L}$ of OPAA solution was vortexed and incubated for $3 \mathrm{~min}$. Finally, $30 \mu \mathrm{L}$ of the final mixture was added for the HPLC.

\section{Fatty acid profile}

The fatty acid composition of the samples was determined using a gas chromatograph (Shimadzu) (AOAC 2005; Herawati et al. 2018). The fatty acid profile of $P$. pacifica could be determined by analyzing its total fatty acid content. The equipment used for this purpose was a gas chromatograph (GCMS) and a QP-2010 Mass Spectrophotometer with a W Cot fused Silica Counting CP-SIL-88 column with $50 \mathrm{~m}$ length, $0.22 \mathrm{~mm}$ diameter, and a column temperature of $120-200^{\circ} \mathrm{C}$. The method employed was in-situ transcertification. A $100 \mathrm{mg}$ sample of $P$. pacifica was homogenized using $4 \mathrm{~mL}$ of water. The resulting $100 \mu \mathrm{L}$ homogenate was then transferred into a reaction tube. One hundred microliters of methylene chloride were then added, along with $1 \mathrm{~mL}$ of $0.5 \mathrm{~N} \mathrm{NaOH}$ in methanol. Once nitrogen was added and the tube was sealed, it was heated to $90^{\circ} \mathrm{C}$ for 10 min. The reaction tube was then cooled, and $1 \mathrm{~mL}$ of $14 \%$ $\mathrm{BF}_{3}$ in methanol was added. After the addition of nitrogen, heating continued at the same temperature for the next 10 min. Next, the reaction tube was cooled to ambient temperature, and $1 \mathrm{~mL}$ of water and $200-500 \mu \mathrm{L}$ of hexane were added. The mixture was then vortexed for $1 \mathrm{~min}$ to extract the fatty acid methyl ester. After centrifugation, the upper layer of the sample was ready for GC analysis.

\section{Water quality parameters}

Measurement of water quality parameters, including temperature $\left({ }^{\circ} \mathrm{C}\right), \mathrm{pH}$, salinity (ppt), and dissolved oxygen $(\mathrm{mg} / \mathrm{L})$, was performed daily in-situ. Dissolved oxygen (DO) was measured using a DO meter, the temperature was measured using a thermometer, and $\mathrm{pH}$ was measured using a pH meter. The results of the measurements of water quality parameters in $P$. pacifica are presented in Table 1.

\section{Data analysis}

Data analyzed included growth rate (r) and biomass weight. If the test results showed that the data were distributed normally and were homogeneous and additive, then the analysis was continued with a one-way analysis of variance (ANOVA) to determine the influence of the observed variables. If there was a significant effect $(\mathrm{P}<$ 0.05), then it was followed by Duncan's multiple range test to determine the pairwise difference in mean values between treatments, and consequently, the best treatment.

\section{RESULTS AND DISCUSSION}

\section{Population density}

Based on population density data during the study, a graph can be made which is presented in Figure 1. The growth pattern on each treatment had the same pattern. The highest growth was on the A treatment (fed by $100 \% C$. vulgaris) on the $12^{\text {th }}$ day of cultivation, which was as many as 58 individuals/L. The lowest population density was on C treatment (fed by $50 \% \quad C$. vulgaris and $50 \% \quad C$. calcitrans) on the $12^{\text {th }}$ day of cultivation which was as many as 20 individuals/L.

\section{Growth rate (r)}

Based on data from the Growth Rate (r) of P. pacifica during the study, a histogram can be made and presented in Figure 2. Based on the ANOVA analysis of growth rates of $P$. pacifica, it showed that different treatment of sea grapes stocking density had a significant effect on the growth of $P$. pacifica $(\mathrm{P}<0.05)$. The growth rate histogram shows the highest growth rate of $0.2418 \mathrm{ind} /$ day in the treatment of $P$. pacifica fed by $100 \%$ C. vulgaris (A), while the lowest growth rate is in the treatment of $P$. pacifica fed by $50 \% C$. vulgaris and $50 \%$ C. calcitrans (C) about 0.1443 Ind/day.

\section{Biomass production}

Biomass production was obtained by weighing Phronima sp. twice, those were before dispersion stocking $\left(\mathrm{W}_{0}\right)$, and on the last day of cultivation or on the $18^{\text {th }}$ day $\left(\mathrm{W}_{\mathrm{t}}\right)$. Phronima sp. biomass production from enrichment with $C$. vulgaris and $C$. calcitrans is presented in Figure 3. The highest biomass production was 0.35 grams in the treatment of feeding $100 \%$ C. vulgaris (A), while the lowest biomass production was in the feeding treatment in the form of a combination of 50\% C. vulgaris and 50\% C. calcitrans which was 0.09 grams. Based on the ANOVA analysis of growth rates of $P$. pacifica, it showed that different treatment of sea grapes stocking density had a significant effect on the growth of $P$. pacifica $(\mathrm{P}<0.05)$.

Table 1. Results of water quality parameter measurement of Phronima pacifica aquaculture

\begin{tabular}{ccccc}
\hline \multirow{2}{*}{ Treatments } & \multicolumn{4}{c}{ Water quality parameter range } \\
\cline { 2 - 5 } & $\begin{array}{c}\text { Temp. } \\
\left({ }^{\circ} \mathbf{C}\right)\end{array}$ & $\mathbf{p H}$ & $\begin{array}{c}\text { DO } \\
(\mathbf{m g} / \mathbf{L})\end{array}$ & $\begin{array}{c}\text { Salinities } \\
(\mathbf{p p t})\end{array}$ \\
\hline $\mathrm{A}$ & $29.2-30.8$ & 8.2 & $4.69-5.38$ & 30 \\
$\mathrm{~B}$ & $28.7-30.5$ & 8.09 & $4.53-4.98$ & 30 \\
$\mathrm{C}$ & $27.2-29.1$ & 8.1 & $4.78-5.05$ & 30 \\
References & $27-31$ & $8.0-9.0$ & $4.7-5.6$ & 30 \\
\hline
\end{tabular}

Note: The references were based on Fattah et al. (2014) 


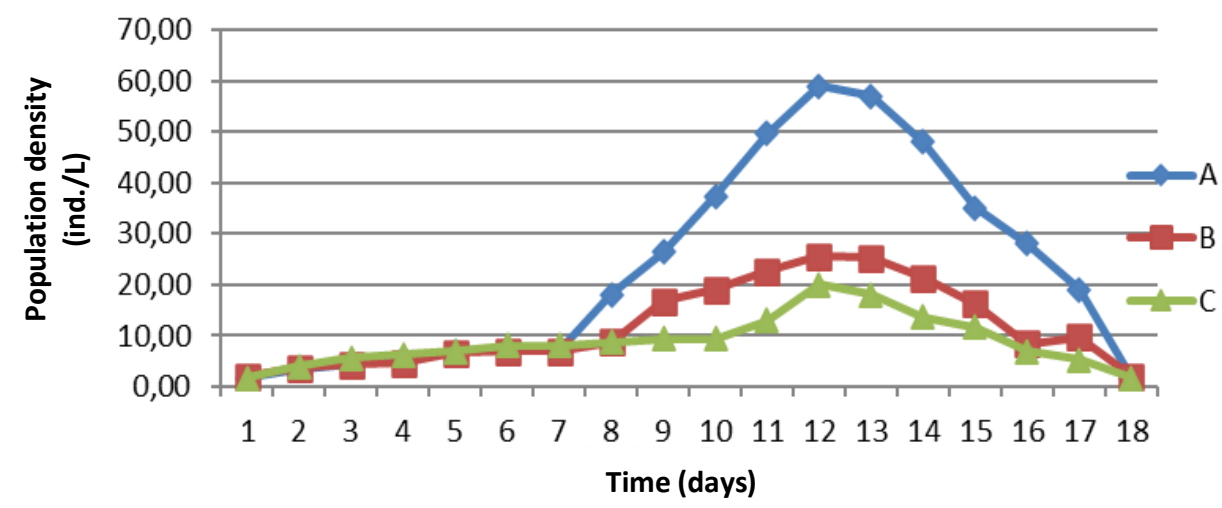

Figure 1. Population density of Phronima pacifica during the study (ind./L)

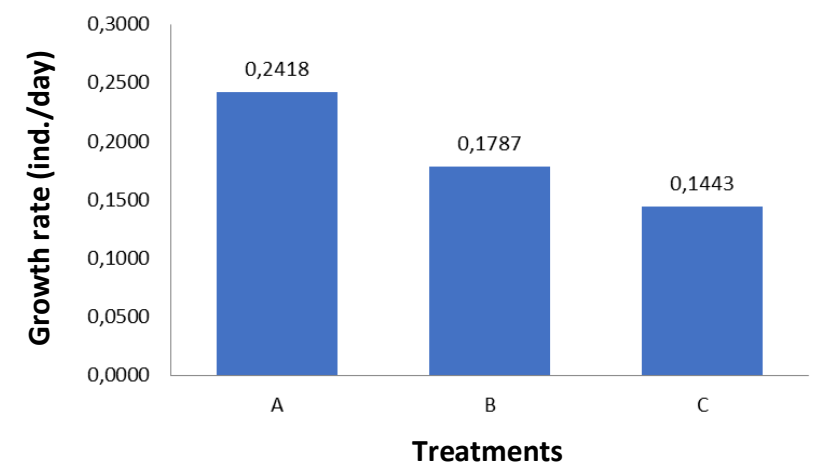

Figure 2. Phronima pacifica growth rate (r) during research (ind./day)

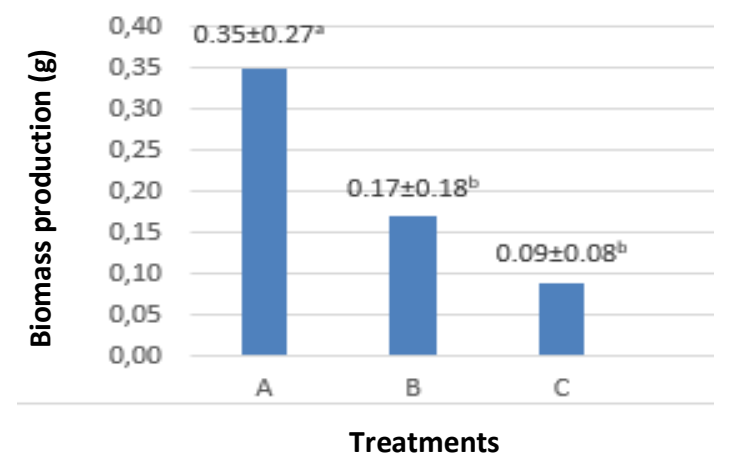

Figure 3. Phronima pacifica biomass production from enrichment with Chlorella vulgaris and Chaetoceros calcitrans

\section{Nutritional quality}

The highest results of the analysis of the nutritional quality of protein and fat of $P$. pacifica could be determined based on the results. The highest value was $45.45 \%$ protein and $7.57 \%$ fat in the treatment of $P$. pacifica fed by $100 \%$ C. vulgaris (A), while the lowest protein and fat was in the feeding treatment in the form of a combination of $50 \%$ C. vulgaris and $50 \%$ C. calcitrans which was $40.44 \%$ and $5.89 \%$. Proximate analysis results of $P$. pacifica are presented in Table 2.
The ANOVA analysis of protein and fat of $P$. pacifica, it showed that different treatment of enrichment feed of $P$. pacifica had a significant effect on the protein and fat of $P$. pacifica $(\mathrm{P}<0.05)$. Based on the results of the analysis of fatty acid profiles of $P$. pacifica, the highest value was in the EPA for about 5.45 in the treatment of $P$. pacifica fed by $100 \%$ C. vulgaris (A), whereas the lowest value was in the treatment of $50 \%$ C. vulgaris and $50 \%$ C. calcitrans, with EPA of $0.68 \%$. The results of analysis of the total fatty acid profile of $P$. pacifica with the enrichment of $C$. vulgaris and $C$. calcitrans during the study are presented in Table 3.

Based on the ANOVA fatty acid profile of $P$. pacifica, it showed that different treatment of enrichment feed of $P$. pacifica had a significant effect on the fatty acid profile of $P$. pacifica $(\mathrm{P}<0.05)$. The results of the analysis of amino acid profiles of $P$. pacifica the highest value was in the amino acid lysine $39.23 \mathrm{ppm}$ in the treatment of feeding $100 \%$ C. vulgaris (A), while the lowest value of the feeding treatment was at a combination of $50 \%$ C. vulgaris and $50 \%$ C. calcitrans with EPA of $18.19 \mathrm{ppm}$. The results of analysis of amino acid profile of $P$. pacifica enriched by $C$. vulgaris and $C$. calcitrans during the study are presented in Table 4. Based on the ANOVA analysis of growth rates of $P$. pacifica, it showed that different treatment of enrichment feed of $P$. pacifica had a significant effect on amino acid profile of $P$. pacifica $(\mathrm{P}<0.05)$.

\section{Discussion}

The results of each treatment included a fairly high population increase phase before a dramatic decline. Each $P$. pacifica treatment experienced the highest phase on the $12^{\text {th }} \mathrm{d}$ of maintenance, before eventually declining in number until the $18^{\text {th }} \mathrm{d}$. Growth patterns in this study exhibited faster maintenance time for the growth of Phronima sp. compared to that of Fattah et al. (2014), who obtained results that increased until the $17^{\text {th }} \mathrm{d}$ and decreased until the $24^{\text {th }} \mathrm{d}$, as well as that of Herawati et al. (2020), who obtained populations that increased until the $16^{\text {th }} \mathrm{d}$ and decreased until the $36^{\text {th }} \mathrm{d}$. 
Table 2. The results of proximate analysis of Phronima pacifica enriched by Chlorella vulgaris and Chaetoceros calcitrans during the study

\begin{tabular}{cccccc}
\hline \multirow{2}{*}{ Treatments } & \multicolumn{5}{c}{ Dry weight content percentage } \\
\cline { 2 - 6 } & Protein (\%) & Carbohydrate (\%) & Crude fat (\%) & Ash (\%) & Crude fiber (\%) \\
\hline A & $45.45 \pm 0.02^{\mathrm{c}}$ & $15.07 \pm 0.05$ & $7.57^{\mathrm{b}} \pm 0.02$ & $26.13 \pm 0.03$ & $5.78 \pm 0.03$ \\
B & $42.90 \pm 0.04^{\mathrm{b}}$ & $16.22 \pm 0.03$ & $6.24^{\mathrm{b}} \pm 0.03$ & $29.19 \pm 0.03$ & $5.45 \pm 0.08$ \\
C & $40.44 \pm 0.06^{\mathrm{a}}$ & $14.87 \pm 0.05$ & $5.89^{\mathrm{b}} \pm 0.02$ & $30.61 \pm 0.02$ & $5.19 \pm 0.05$ \\
\hline
\end{tabular}

Note: A: $100 \%$ C. vulgaris, B: $100 \%$ C. calcitrans, C: $50 \%$ C. vulgaris and 50\% C. calcitrans

Table 3. The results of analysis of the total fatty acid profile of Phronima pacifica enriched by Chlorella vulgaris and Chaetoceros calcitrans during the study

\begin{tabular}{|c|c|c|c|}
\hline $\begin{array}{l}\text { Fatty acids } \\
\text { profile }(\%)\end{array}$ & $\mathbf{A}$ & B & C \\
\hline Myristic & $0.52 \pm 0.05^{\mathrm{a}}$ & $0.48 \pm 0.09^{\mathrm{a}}$ & $0.41 \pm 0.02^{\mathrm{a}}$ \\
\hline Pentadecanoic & $0.09 \pm 0.06^{\mathrm{a}}$ & $0.15 \pm 0.08^{\mathrm{a}}$ & $0.17 \pm 0.04^{\mathrm{a}}$ \\
\hline Palmitic & $3.14 \pm 0.09^{\mathrm{b}}$ & $5.59 \pm 0.04^{c}$ & $1.97 \pm 0.08 \mathrm{a}$ \\
\hline Stearic & $2.71 \pm 0.07^{b}$ & $2.91 \pm 0.09^{\mathrm{b}}$ & $0.52 \pm 0.03^{\mathrm{a}}$ \\
\hline Oleic/ $\omega 9$ & $3.07 \pm 0.02^{\mathrm{b}}$ & $2.61 \pm 0.01^{b}$ & $0.89 \pm 0.08^{\mathrm{a}}$ \\
\hline Linoleic/ $\omega 6$ & $4.83 \pm 0.09^{b}$ & $5.37 \pm 0.02^{\mathrm{c}}$ & $2.49 \pm 0.07^{\mathrm{a}}$ \\
\hline Linolenic/ $\omega 3$ & $3.54 \pm 0.05^{\mathrm{b}}$ & $3.32 \pm 0.01^{b}$ & $2.39 \pm 0.03^{b}$ \\
\hline $\mathrm{AA}$ & $2.71 \pm 0.03^{b}$ & $0.13 \pm 0.07^{b}$ & $0.15 \pm 0.09^{b}$ \\
\hline DHA & $2.83 \pm 0.05^{\mathrm{b}}$ & $1.17 \pm 0.03^{b}$ & $0.97 \pm 0.01^{\mathrm{a}}$ \\
\hline EPA & $5.95 \pm 0.02^{c}$ & $3.88 \pm 0.08^{b}$ & $0.68 \pm 0.02 \mathrm{a}$ \\
\hline
\end{tabular}

Note: A: $100 \%$ C. vulgaris, B: $100 \%$ C. calcitrans, C: $50 \%$ C. vulgaris. and $50 \%$ C. calcitrans. Different superscript letter indicates significant differences between treatments $(p<0.05)$
Table 4. Phronima pacifica enriched by Chlorella vulgaris and Chaetoceros calcitrans during the study

\begin{tabular}{|c|c|c|c|}
\hline \multirow{2}{*}{$\begin{array}{l}\text { Amino acid } \\
(\text { ppm })\end{array}$} & \multicolumn{3}{|c|}{ P. pacifica } \\
\hline & $\mathbf{A}$ & B & C \\
\hline L-aspartic acid & $18.92 \pm 0.08^{c}$ & $13.94 \pm 0.01^{b}$ & $5.52 \pm 0.05^{\mathrm{b}}$ \\
\hline L-serine & $17.62 \pm 0.01^{\mathrm{a}}$ & $17.62 \pm 0.01^{\mathrm{a}}$ & $14.76 \pm 0.02^{\mathrm{a}}$ \\
\hline L-glutamic acid & $32.37 \pm 0.07^{c}$ & $12.37 \pm 0.07^{\mathrm{b}}$ & $17.36 \pm 0.07^{\mathrm{b}}$ \\
\hline Glycine & $19.19 \pm 0.01^{\mathrm{a}}$ & $19.19 \pm 0.01^{\mathrm{a}}$ & $17.33 \pm 0.02^{\mathrm{a}}$ \\
\hline L-histidine & $9.70 \pm 0.01^{\mathrm{a}}$ & $9.70 \pm 0.01^{\mathrm{a}}$ & $8.65 \pm 0.03^{\mathrm{a}}$ \\
\hline L-arginine & $27.28 \pm 0.01^{\mathrm{c}}$ & $20.28 \pm 0.01^{\mathrm{c}}$ & $10.85 \pm 0.07^{\mathrm{c}}$ \\
\hline L-threonine & $20.37 \pm 0.01^{\mathrm{c}}$ & $10.37 \pm 0.01^{\mathrm{c}}$ & $18.47 \pm 0.07^{c}$ \\
\hline L-alanine & $21.51 \pm 0.09^{c}$ & $12.51 \pm 0.09^{c}$ & $10.51 \pm 0.01^{\mathrm{c}}$ \\
\hline L-proline & $19.00 \pm 0.06^{c}$ & $15.00 \pm 0.06^{c}$ & $9.08 \pm 0.09^{c}$ \\
\hline L-valine & $28.87 \pm 0.04^{\mathrm{c}}$ & $17.87 \pm 0.04^{\mathrm{c}}$ & $5.72 \pm 0.03^{c}$ \\
\hline L-methionine & $15.40 \pm 0.04^{\mathrm{c}}$ & $8.57 \pm 0.04^{c}$ & $5.89 \pm 0.06^{\mathrm{c}}$ \\
\hline L-Lysine & $39.23 \pm 0.01^{\mathrm{c}}$ & $25.73 \pm 0.01^{\mathrm{c}}$ & $18.19 \pm 0.06^{\mathrm{c}}$ \\
\hline L-isoleucine & $22.79 \pm 0.04^{c}$ & $17.53 \pm 0.04^{c}$ & $8.87 \pm 0.02^{\mathrm{c}}$ \\
\hline L-leucine & $16.88 \pm 0.05^{\mathrm{c}}$ & $8.88 \pm 0.05^{\mathrm{c}}$ & $11.47 \pm 0.05^{\mathrm{c}}$ \\
\hline L-phenylalanine & $15.49 \pm 0.07^{\mathrm{b}}$ & $16.98 \pm 0.10^{b}$ & $14.41 \pm 0.07^{\mathrm{b}}$ \\
\hline
\end{tabular}

Phronima pacifica experienced an increase in population density and then decreased significantly. This could be caused by individuals that had entered the phase of death. This death phase could be caused by the death of plankton that was the food source for P. pacifica. This is in accordance with the results of Aoki et al. (2013), who stated that the decrease in the number of Phronima sp. occurred because excess nutrients were not utilized effectively such they produced a large amount of toxic organic material and the amount of plankton as a natural feed source for Phronima sp. was not sufficient for its needs.

Enrichment of the $P$. pacifica mass culture with $C$. vulgaris and $C$. calcitrans yielded different growth results. The results showed the highest growth and biomass in $P$. pacifica mass cultures were yielded by feeding $100 \% C$. vulgaris (treatment A), with the highest growth of 59 ind./L (Figure 1), the highest biomass was $0.35 \mathrm{~g}$ (Figure 3), and the growth rate was $0.24 \%$ (Figure 2). This was because the difference in size and nutrient content of $C$. vulgaris was 2$10 \mu \mathrm{m}$ (with $45 \%$ protein and $20 \%$ fat) and that of $C$. calcitrans was $10-50 \mu \mathrm{m}$ (with $36 \%$ protein and $10 \%$ fat). The higher nutrient content and smaller size of $C$. vulgaris resulted in a density of 59 ind./L, biomass production of $0.35 \mathrm{~g}$, and $0.24 \%$ growth rate of $P$. pacifica, which was higher than that of those that feed on $C$. calcitrans, which resulted in a yield of 20 ind./L, biomass production of 0.09 g, and $0.14 \%$ growth rate of $P$. pacifica because $C$. vulgaris is more easily digested by $P$. pacifica as feed. This statement was reinforced by previous studies conducted by Ball (1977) and Diebel (1988), wherein a nonselective filter feeder received an addition of nutrients through the media. Thus, growth is highly dependent on the feed and culture media of $P$. pacifica.

The results of this study were lower than those of Herawati et al. (2020), wherein the mass culture of Phronima sp. used a culture media in the form of fermented organic waste, which resulted in a density of 98 ind./L and biomass production of $0.51 \mathrm{~g}$ over $35 \mathrm{~d}$ of rearing. Enrichment using $C$. vulgaris and $C$. calcitrans was not sufficient to provide better results because the culture media nutrient was highly influenced by the supply of plankton and bacteria, by which the population and biomass growth increased. Growth and production of $P$. pacifica biomass are influenced not only by the nutrient content in the culture media but also by environmental conditions. According to Agung et al. (2104), plankton growth patterns are influenced by several factors, including the physical condition of the water, type of feed, and concentration of the feed. When these three factors are optimal, the growth rate of plankton will increase and produce a higher population peak. One of the influential environmental conditions was water quality in the culture media of $P$. pacifica. During the culture period of the $P$. 
pacifica culture media, water quality was controlled by measuring water parameters daily. Water quality was measured in situ.

Growth of $P$. pacifica showed the same pattern as maintenance media. Although the amount in each media was different, the phases of increase and decrease and relative to the amount received were relatively the same. Differences in the number of $P$. pacifica in different maintenance media showed that the nutrient content in each medium was different and nutrients affected the growth of $P$. pacifica. The difference in population density was caused by the ability of cells to utilize nutrients for growth. Nutrients in culture media will affect the amount of phytoplankton contained in the media, and nitrate determines the amount of phytoplankton that functions as a natural feed source for $P$. pacifica, as well as bacteria and detritus contained in the media. Based on the results, the highest abundance of plankton that grew and dominated the culture media was Chlorella sp. Agung et al. (2104) in their research explained that the greater the abundance of phytoplankton and organic matter contained in the media, the greater the growth rate.

Nutritional quality based on proximate analysis, as shown in Table 2, showed that the highest values of protein and fat were observed in $P$. pacifica fed $C$. vulgaris being $45.45 \%$ and $7.57 \%$, respectively. Additionally, the lowest values occurred in the treatment wherein $P$. pacifica was fed $50 \%$ C. vulgaris and $50 \%$ C. calcitrans. High protein content and low fat resulted in high nutrients in the culture media of $P$. pacifica, and higher nitrate and phosphate levels resulted from the higher protein level produced. Tocher and Glencross (2015) stated that the higher the $\mathrm{N}$ and $\mathrm{P}$ content, the higher the protein content in the culture. The fat content was inversely proportional to protein content. The results of this study were supported by the results of Lim et al. (2011), who stated that higher protein content was always proportional to fat because the fat in the body works twice as much as protein.

Based on the total fatty acid profile (Table 3), the highest fatty acid profile for EPA occurred for the $P$. pacifica fed $C$. vulgaris, whereas the lowest value was observed in P. pacifica fed $50 \%$ C. vulgaris and $50 \%$ C. calcitrans, which was $2.64 \%$. EPA fatty acids function as a basic substrate in the formation of long-chain polyunsaturated fatty acids (PUFAs) and help to avoid blood clotting. The results of this study were higher than those of Herawati et al. (2020), wherein a $P$. pacifica mass culture using fermented organic waste from probiotic bacteria as feed had an EPA content of $5.95 \%$. PUFAs are an important nutrient for the formation of LC-PUFAs, such that it could form or be able to produce EPA and DHA and help avoid blood clotting. The results of this study were reinforced by the findings of Monroig et al. (2013), and Tocher and Glencross (2015), in which PUFAs were a very important nutrient for the formation of LC PUFAs, from which EPA and DHA are formed, depending on the species.

Based on the results of the amino acid profile of $P$. pacifica, the highest value was observed in $P$. pacifica fed C. vulgaris, whereas the lowest value was observed in $P$. pacifica fed $50 \%$ C. vulgaris and $50 \%$ C. calcitrans, which was $2.64 \%$. The function of the amino acid lysine, as stated in the research of Ovie and Ovie (2006), Valverde et al. (2013), and Herawati et al. (2017) is to serve as a structural framework for vitamin B1 and anti-virals, increasing the absorption of calcium, stimulating appetite, and aiding in the production of carnitine to convert fatty acids into energy. The high content of lysine in P. pacifica with a natural feed could increase growth, and it is also a basic ingredient of blood antibodies, strengthens the circulatory system, and improves cells. Lysine deficiency can cause fin erosion and fish death. This is in line with the results of Nafisi Bahabadi et al. (2018), who stated that the function of lysine in fish growth was very important, among others reasons, for the basic ingredients of blood antibodies, strengthening of the circulation system and metabolism, and the repair of cells. Based on an ANOVA, feeding $P$. pacifica with $C$. vulgaris and $C$. calcitrans had a significant effect on population density, relative growth rate, biomass production, and nutrient values for protein and fat in $P$. pacifica $(\mathrm{P}<0.05)$. The best research results were for $P$. pacifica fed $C$. vulgaris, which resulted in better growth, including population density, growth rate, biomass weight, and nutrient content.

In conclusion, the utilization of $C$. vulgaris and $C$. calcitrans as enrichment for $P$. pacifica culture had been reported. Enrichment of the $P$. pacifica mass-cultured with C. vulgaris (treatment A) resulted in the highest growth of 59 ind./L (Figure 1), the highest biomass was $0.35 \mathrm{~g}$ (Figure 3), and the growth rate was $0.24 \%$ (Figure 2). The highest values for proteins and fats were also in (treatment A) and consisted of $45.45 \%$ protein, $7.57 \%$ fat, $5.95 \%$ eicosapentaenoic acid, and $39.23 \%$ lysine. Since there have been no studies that report on the effects of providing different types of natural feed on the nutritional content of $P$. pacifica, the results of this study should have quite impact on improving quality of $P$. pacifica as natural feed.

\section{ACKNOWLEDGEMENTS}

This study was done for Research Program, funded by Diponegoro University, Indonesia, under grant number of 039/UN7.5.10.2/PP/2020.

\section{REFERENCES}

Agung, Indra G, Lutfi M, Nugroho WA. 2014. Effect of addition of light at night to the growth of Chlorella sp. in the tofu industrial liquid waste treatment plant of recirculate raceway pond type. J Eng Trop Agric Biosyst 2 (3): 287-296.

AOAC. 2005. AOAC Official Methods of Analysis, 18th ed. Association of Official Analytical Chemist, Arlington, V.A.

Aoki MN, Ohshima CM, Hirose E, Nishikawa J. 2013. Mother-young cohabitation in Phronimella elongata and Phronima sp. (Amphipoda, Hyperiidea, Phronimidae). J Mar Biol Assoc UK 93 (6): 1553-1556.

Baeza-Rojano E, Calero-Cano S, Hachero-Cruzado I, Guerra-García JM. 2013. A preliminary study of the Caprella scaura amphipod culture for potential use in aquaculture. J Sea Res 83: 146-151. DOI: 10.1016/j.seares.2013.04.014 
Ball EE. 1977. Fine structure of the compound eyes of the midwater amphipod Phronima in relation to behavior and habitat. Tissue Cell 9 (3): 521-536

Bishop R, Geiger S. 2006. Phronima energetics: Is there a bonus to the barrel? Crustaceana 79 (9): 1059-1070.

Diebel CE. 1988. Observations on the anatomy and behavior of Phronima sedentaria (Forskal) (Amphipoda: Hyperiidea). J Crustacean Biol 8 (1): 79-90.

Dalpadado P, Bogstad B. 2004. Diet of juvenile cod (age 0-2) in the Barents Sea in relation to food availability and cod growth. Polar Biol 27 (3): 140-154.

Elder LE, Seibel BA. 2015. The thermal stress response to diel vertical migration in the hyperiid amphipod Phronima sedentaria. Comp Biochem Physiol Part A: Mol Integr Physiol 187: 20-26.

Fattah MH, Saenong M, Asbar, Rahbiah SB. 2014. Production of endemic microcrustacean Phronima Suppa (Phronima sp.) to subtitute Artemia salina in Tiger Prawn cultivation. J Aquac 5 (5): 1-5.

Herawati VE, Agus M. 2014. Analysis of growth and survival of catfish (Clarias gariepinus) larvae fed by Daphnia sp. mass cultured using fermented organic fertilizers. J Aquac Manag Technol (26): 1-11.

Herawati VE, Hutabarat J, Radjasa OK. 2015. Growth and survival rate of Tilapia (Oreochromis niloticus) larvae fed by Daphnia magna cultured with organic fertilizer resulted from probiotic bacteria fermentation. Hayati J Biosci 22 (4): 169-173.

Herawati VE, Nugroho RA, Pinandoyo, Darmanto YS, Hutabarat J. 2017. Nutritional value content, biomass production and growth performance of Daphnia magna cultured with different animal wastes resulted from probiotic bacteria fermentation. IOP Conf Ser Earth Environ Sci 55: 12004. DOI: 10.1088/1755-1315/55/1/012004.

Herawati VE, Nugroho RA, Pinandoyo, Darmanto YS, Hutabarat J. 2018 The effect of fermentation time with probiotic bacteria on organic fertilizer as Daphnia magna cultured medium towards nutrient quality, biomass production and growth performance enhancement. IOP Conf Ser Earth Environ Sci 116: 1-11. DOI: 10.1088/17551315/116/1/012089

Herawati VE, Pinandoyo P, Rismaningsih N, Darmanto D, Hutabarat J, Radjasa OK. 2020. The effect of probiotic bacteria in culture media using organic fertilizer for population density, biomass production and nutrient quality of Phronima sp. as natural feed. Aquac Res 51 (2): $836-843$

Krebs CJ. 1972. The Experimental Analysis of Distribution and Abundance. Ecology. Harper and Row, New York.

Lim CM, Aksoy Y, Klesius P. 2011. Lipid and fatty acid requirements of Tilapia, North America. Indon J Aquat Sci Fish 73 (2): 188-193. DOI: 10.1080/15222055.2011.579032.

Lowry JK, Myers AA. 2017. A phylogeny and classification of the Amphipoda with the establishment of the new order Ingolfiellida (Crustacea: Peracarida). Zootaxa 4265 (1): 1-89.

Méndez-Martínez Y, García-Guerrero MU, Lora-Vilchis MC, MartínezCórdova LR, Arcos-Ortega FG, Alpuche JJ, Cortés-Jacinto E. 2018. Nutritional effect of Artemia nauplii enriched with Tetraselmis suecica and Chaetoceros calcitrans microalgae on growth and survival on the river prawn Macrobrachium americanum larvae. Aquacult Intl 26 (4): 1001-1015.

Monroig Ó, Tocher DR, Navarro JC. 2013. Biosynthesis of polyunsaturated fatty acids in marine invertebrates: recent advances in molecular mechanisms. Mar Drugs 11 (10): 3998-4018.

Nafisi Bahabadi M, Torfi Mozanzadeh M, Agh N, Ahmadi A, Yaghoubi M. 2018. Enriched Artemia with L-lysine and DL-methionine on growth performance, stress resistance, and fatty acid profile of Litopenaeus vannamei postlarvae. J Appl Aquacult 30 (4):.325-336.

Ovie SI, Ovie SO. 2006. Moisture, protein, and amino acid contents of three freshwater zooplankton used as feed for aquacultured larvae and postlarvae. Isr J Aquac Bamidgeh 58 (1): 29-33.

Sihombing RF, Aryawati R, Hartoni. 2013. The content of chlorophyll-a phytoplankton around the waters of the village of Sungsang, Banyuasin District, South Sumatra Province. Maspari J 5 (1): 34-39.

Tocher DR, Glencross BD. 2015. Lipids and fatty acids. In: Lee CS, Lim C, Webster C, Gatlin DM III (eds.). Dietary Nutrients, Additives, and Fish Health. Wiley-Blackwell, Hoboken, NJ.

Valverde JC, Martínez-Llorens S, Vidal AT, Jover M, Rodríguez C, Estefanell J, Gairín JI, Domingues PM, Rodríguez CJ, García BG. 2013. Amino acids composition and protein quality evaluation of marine species and meals for feed formulations in cephalopods. Aquac Intl 21 (2): 413-433. 